\title{
SERVIDÃO E SUPERAÇÃO: \\ UM ESTUDO ACERCA DA PRESENÇA DA EMPREGADA DOMÉSTICA NA OBRA DE CLARICE LISPECTOR
}

\author{
Patrícia Ferreira Alexandre de Lima*
}

\begin{abstract}
RESUMO: Este estudo tem como objeto a figuração da empregada doméstica na obra de Clarice Lispector. Pretendemos refletir as relações provenientes de um passado escravocrata brasileiro que desembocam na forma como se dá a contratação de empregadas domésticas até hoje. A doméstica está presente em contos e romances de Clarice, e ainda, em crônicas que publicou no Jornal do Brasil. Detivemo-nos a uma análise mais próxima das domésticas Augusta, do conto "Um dia a menos" e Janair, do romance A paixão segundo G.H. Sabemos que o trabalho doméstico também engloba o gênero masculino, entretanto, nesta abordagem, instituímos como recorte o trabalho doméstico desenvolvido apenas por mulheres por dois motivos: o primeiro está ligado à própria figuração na obra de Clarice, em que as personagens são do sexo feminino, o segundo se refere ao fato de o trabalho doméstico ser realizado majoritariamente por mulheres. Esperamos, desta forma, por meio da abordagem da obra de uma escritora que foi tantas vezes cobrada por não ter uma escrita engajada socialmente, contribuir para o debate acerca das relações que precarizam e desvalorizam o trabalho doméstico no Brasil.
\end{abstract}

PALAVRAS-CHAVE: Clarice Lispector; empregada doméstica; invisibilidade.

É uma pauta presente em nossos dias a discussão acerca de não falar pelo outro, de não sufocar o grito do oprimido, mas de proporcionar o espaço necessário para que essa voz seja ouvida. Nesse sentido, Clarice Lispector se mostra uma escritora à frente do seu tempo, quando traz para o espaço intelectual a representação da empregada doméstica, presente em muitas de suas obras.

Encontramos uma recorrente leitura da obra de Clarice que considera $A$ bora da estrela como o único trabalho em que a escritora traz as questões sociais ao debate, especialmente quando a análise associa a obra clariceana a aspectos existencialistas, detendo-se apenas ao exame do fluxo de consciência de seus personagens, citamos como exemplo dessa abordagem, a crônica "Clarice: impressões de uma mulher que lutou sozinha", publicada poucos dias após o falecimento da escritora, em que o jornalista Paulo Francis, que havia sido seu editor na revista Senhor, comenta o registro da imprensa brasileira acerca da morte da escritora e questiona se é sabido que, em 1959, Clarice não conseguia publicar seu trabalho exatamente por sua escrita, para Francis, não voltada para o social:

Tinha fama, sim, mas entre intelectuais e escritores. Os editores a evitavam como a praga. Os motivos me parecem óbvios: ela não é discípula do "realismo socialista", ou preocupada com os pequenos dramas da pequena burguesia brasileira. $\mathrm{Na}$ literatura de Clarice não há estrutura social definida. Sensibilidade e sensações predominam, a "realidade" é vista em relances, indireta e indutivamente. (FRANCIS, 1977, p. 43, grifos do autor)

\footnotetext{
* Mestre em Letras pela Universidade Federal do Paraná (UFPR).
} 
Essa leitura da obra também é percebida quando a análise se dá em outras áreas do conhecimento, como na sociologia, filosofia a até nas artes visuais, já que o livro foi adaptado para o cinema em 1985, com direção de Suzana Amaral que afirmou em entrevista ao Programa Trinta Anos Incríveis, da TV Cultura:

[...] curiosamente é único livro da Clarice no qual ela toca o problema social do Brasil porque todos os outros livros dela são sempre viagens dentro dela mesma, na classe média que é a origem dela, são muito mais problemas íntimos e devaneios psicológicos e emocionais e esse não, esse daí tem isso tudo mas ao mesmo tempo também, tem um olhar sobre o problema social do Brasil. (TV Cultura, Programa Trinta Anos Incríveis, 1999).

Desta forma, $A$ hora da estrela foi recebido como uma resposta à questão muitas vezes cobrada de Clarice: uma escrita militante, porém, acreditamos que esse trabalho se constitui como um ponto de chegada em sua literatura, estando a representação social sempre presente, sob um viés de delicadeza e originalidade. Acerca do fato social, Clarice se manifestou, por exemplo, por meio da crônica "Literatura e justiça", publicada em 1964:

Desde que me conheço o fato social teve em mim importância maior do que qualquer outro: em Recife os mocambos foram a primeira verdade para mim. Muito antes de sentir "arte", senti a beleza profunda da luta. Mas é que tenho um modo simplório de me aproximar do fato social: eu queria era "fazer" alguma coisa, como se escrever não fosse fazer. O que não consigo é usar escrever para isso, por mais que a incapacidade me doa e me humilhe. O problema de justiça é em mim um sentimento tão óbvio e tão básico que não consigo me surpreender com ele $-\mathrm{e}$, sem me surpreender, não consigo escrever. E também porque para mim escrever é procurar. O sentimento de justiça nunca foi procura em mim, nunca chegou a ser descoberto, e o que me espanta é que ele não seja igualmente óbvio em todos. (LISPECTOR, 1999, p. 29).

Na página em que manteve no Jornal do Brasil, entre os anos de 1967 a 1973, a escritora expôs a sua opinião sobre diversos assuntos, inclusive sobre as questões sociais. Exemplo disso é a crônica publicada em 16/09/1967, intitulada "Daqui a vinte e cinco anos":

Perguntaram-me uma vez se eu saberia calcular o Brasil daqui a vinte e cinco anos. Nem daqui a vinte e cinco minutos, quanto mais vinte e cinco anos. Mas a impressão-desejo é a de que num futuro não muito remoto talvez compreendamos que os movimentos caóticos atuais já eram os primeiros passos afinando-se e orquestrando-se para uma situação econômica mais digna de um homem, de uma mulher, de uma criança. E isso porque o povo já tem dado mostras de ter maior maturidade política do que a grande maioria dos políticos, e é quem um dia terminará liderando os líderes. Daqui a vinte e cinco anos o povo terá falado muito mais. Mas se não sei prever, posso pelo menos desejar. (LISPECTOR, 1999a, p. 33).

Clarice não pôde conhecer os 25 anos subsequentes a sua crônica, tendo a escritora falecido em 1977, e infelizmente o seu desejo não se concretizou, passados 53 anos dessa publicação, o Brasil está submerso em uma profunda crise econômica, social e de saúde pública, fator este agravado pela Pandemia do Corona Vírus que estamos mundialmente 
atravessando. $\mathrm{O}$ fato é que, além de não ter atingido essa maturidade política referida por Clarice, a população brasileira está cada vez mais longe da possibilidade de liderar os seus gestores, que atendem e governam para um grupo de privilegiados. Também no Jornal do Brasil, a escritora reflete sobre os índios:

\begin{abstract}
Sabe-se que uma das preocupações constantes da Constituição Brasileira é a preservação do nosso índio; nela existe um preceito constitucional que garante ao índio a posse da terra por ele ocupada. Parece incrível que a este preceito constitucional, justamente, é que se deve a matança dos índios. A cobiça da terra ocupada por eles. (LISPECTOR, 1999a, p. 104).
\end{abstract}

Esta crônica foi publicada em 18/05/1968, ao longo das décadas que se sucederam à publicação, assistimos não apenas ao extermínio de muitas etnias, como a tentativa de desmonte das proteções legais que têm os índios em relação ao direito de posse de suas terras.

Clarice dirigiu-se ainda ao Ministro da Educação, por meio de um texto publicado em 17/02/1968 intitulado "Carta ao Ministro da Educação": "Em primeiro lugar queríamos saber se as verbas destinadas para a educação são distribuídas pelo senhor. Se não, esta carta deveria se dirigir ao Presidente da República.” (LISPECTOR, 1999a, p. 76). A escritora se refere à decisão do MEC de fazer constar nos editais de vestibular que os concursos sejam classificatórios, aprovando apenas os primeiros colocados entre os candidatos e deixando os "excedentes" sem vagas:

[...] 'excedentes' num país que ainda está em construção?! e que precisa com urgência de homens e mulheres que o construam? Só deixar entrar nas faculdades os que tiverem melhores notas é fugir completamente ao problema. [...] Não estou de modo algum entrando em seara alheia. Esta seara é de todos nós. (LISPECTOR, 1999a, p. 77).

Assim como é de todos nós o problema da fome, relatado por Clarice tantas vezes por meio do pensamento dos seus personagens que refletem sobre o tema. Quando no conto “Amor" a protagonista Ana se encontra no Jardim Botânico, pensa nos que sentem fome: "Quando Ana pensou que havia crianças e homens grandes com fome, a náusea subiu-lhe à garganta, como se ela estivesse grávida e abandonada.” (LISPECTOR, 1999b, p. 25). Ao escrever sobre Macabéa, Rodrigo S.M. pontua: “Se o leitor possui alguma riqueza e vida bem acomodada, sairá de si para ver como é às vezes o outro. Se é pobre, não estará me lendo porque ler-me é supérfluo para quem tem uma leve fome permanente.” (LISPECTOR, 2007, p. 34). E a própria Clarice se manifestou na crônica "Os prazeres de uma vida normal", publicada em 21/09/1968: "E como é bom comer, dá até vergonha. E certo orgulho também, o orgulho de se ser um corpo exigente. Ah que me perdoem os que não têm o que comer; o que vale é que esses não são os que me leem.” (LISPECTOR, 1999a, p. 137). 
A escritora apresenta no plano intelectual a questão da miséria alheia, reconhecendo a sua impotência, mas fazendo emergir um gesto político em uma dimensão da ética do comprometimento com o outro. Nesse sentido, a escrita social em Clarice se descola do explícito, operando o político de forma diferente, abordando a dor do outro de maneira muito mais original, convidando o leitor a integrar uma estética sensível e humanitária, inclusive no âmbito da experimentação, quando, por exemplo, na crônica "Mineirinho", que trata sobre um bandido que foi assassinado com treze tiros, "quando um só bastava", diz Clarice, a escritora afirma: "O décimo terceiro tiro me assassina - porque eu sou o outro. Porque eu quero ser o outro" (LISPECTOR, 1999, p. 124).

É no escopo da experimentação e da aproximação que Clarice toca no social, a escritora, integrou a classe média do Rio de Janeiro quando retornou ao Brasil, em 1959, tendo estado por 16 anos acompanhando o ex-marido diplomata por diversos países. Aqui, Clarice, assim como as demais mulheres de sua classe social, convive com a presença das empregadas domésticas, frequentemente retratadas em sua obra.

Aliás, devemos salientar que a mulher de classe média não tinha uma representação em nossa literatura antes de Clarice e que a voz dessa mulher se dá a partir de um lugar de classe. Sobre a representação da mulher de classe média na obra de Clarice Lispector, Gotlib reflete:

\begin{abstract}
Este tema, muito presente ao longo de toda história de sua narrativa, atinge, nesta "hora da ficção" de $A$ hora da estrela, um alto grau de extrema periclitância, talvez porque se trate de uma história que acontece, segundo afirma o próprio narrador, "em estado de emergência e de calamidade pública". Porque aqui não se trata só da mulher, mulher burguesa, como quase todas as mulheres de sua ficção. Tratase da mulher burguesa no confronto com a mulher nordestina pobre. A mulher instruída diante da mulher sem instrução. A quem tem diante da que não tem (GOTLIB, 2017, p. 185).
\end{abstract}

Se em $A$ hora da estrela este cotejo é colocado de forma mais radical, são abundantes os momentos na obra em que enquanto as personagens clariceanas se deslocam de suas realidades cotidianas e entram em contato com elementos que desmontam suas estruturas internas, há uma outra mulher, a empregada, a quem as atividades domésticas foram delegadas. É assim, por exemplo, com Ana, do conto "Amor"; com Margarida Flores, do conto "Um dia a menos”; com G. H., em A paixão segundo G. H.; e até mesmo com Rodrigo S.M., que em um dado momento da narrativa, afirma: "O que se segue é apenas uma tentativa de reproduzir três páginas que escrevi e que minha cozinheira, vendo-as soltas, jogou no lixo para o meu desespero [...]” (p. 50).

Também em sua coluna, no Jornal do Brasil, Clarice falou sobre as empregadas domésticas, entre os trechos que selecionamos, iniciaremos com a análise da crônica "Por detrás da devoção", em que a escritora afirma: 
Por falar em empregadas, em relação às quais sempre me senti culpada e exploradora, piorei muito depois que assisti à peça As criadas, dirigida pelo ótimo Martim Gonçalves. Fiquei toda alterada. Vi como as empregadas se sentem por dentro, vi como a devoção que às vezes recebemos delas é cheia de um ódio mortal. Em As criadas, de Jean Genet, as duas sabem que a patroa tem de morrer. Mas a escravidão aos donos é arcaica demais para poder ser vencida. E, em vez de envenenar a terrível patroa, uma delas toma o veneno que lhe destinava, e a outra criada dedica o resto da vida a sofrer. (LISPECTOR, 1999a, p. 50).

Sobre a figuração da empregada doméstica nas crônicas que Clarice escreveu para o Jornal do Brasil, Roncador afirma:

\begin{abstract}
Em suas crônicas para o Jornal do Brasil, ao contrário, o reconhecimento da autora das diferenças entre empregadas e patroas (inclusive aquelas relacionadas ao cultivo da beleza e da moda) aporta o leitor para uma zona de culpas e constrangimentos, em que Lispector igualmente se reconhece cúmplice, como patroa ela mesma, da relação de exploração econômica das empregadas domésticas. (RONCADOR, 2008, p. 145).
\end{abstract}

Clarice reflete sobre a relação de escravidão posta, herança de um Brasil escravocrata, um país que apenas em 2015 equiparou os direitos das empregadas domésticas aos dos trabalhadores das demais categorias. A escritora está, nesta crônica, referindo-se a sua empregada, Aninha, que a surpreendeu pedindo um livro de Clarice para ler: "[...] me pediu com vOz mais abafada ainda para ler um dos meus livros, que eu respondi que eram complicados demais, ao que ela retrucou com o mesmo tom de voz que era disso que gostava, não gostava de água com açúcar. (LISPECTOR, 1999a, p. 49).

A escritora se justifica na crônica que não queria um clima de literatura em casa e que esta era a razão pela qual ao invés de dar um livro seu para Aninha ler, oferecer um outro, que havia traduzido. Depois se surpreende porque Aninha considerou o livro “pueril”. Esta crônica é de 02/12/1967, na coluna da semana anterior, em 25/11/1967, Clarice também havia falado sobre Aninha, o título da crônica é "A mineira calada”, em que relata a curiosidade da empregada acerca do fato de a patroa ser escritora, em "Por detrás da devoção", conclui: "Pois bem, ela se transformou. Como se desenvolveu aqui em casa! Até puxa conversa, e a voz agora é muito mais clara.” (LISPECTOR, 1999a, p. 49).

Aninha foi da mudez à comunicação com a sua patroa, que lhe deu espaço e oportunidade de ser ouvida, suprimindo, pelo menos no âmbito da conversação, a diferença de classe entre ambas, pois como a escritora relatou, sentia-se culpada e exploradora em relação às empregadas domésticas.

Ainda em "Por detrás da devoção", Clarice fala sobre outras quatro empregadas: Jandira, a cozinheira vidente, uma argentina que a bajulava, uma terceira que se mudou com Clarice para os Estados Unidos e lá permaneceu depois que esta voltou para o Brasil, tendo 
inclusive, posteriormente, convidado a escritora para visitá-la e por fim, uma empregada que para surpresa da escritora fazia análise:

E a empregada que tive e não posso dar seu nome por uma questão de segredo profissional? Fazia análise, juro... Duas vezes por semana ia ver uma Dra. Neide. Telefonava-lhe nos momentos de angústia. No começo não disse que saía para ser psicanalisada, dava outros pretextos. Até que um dia contou que a Dra. Neide achava que eu ia compreender e que ela devia falar a verdade. Compreendi, mas terminei não suportando.” (LISPECTOR, 1999a, p. 51).

Segundo Clarice, a empregada tinha uma voz "aguda e altíssima" e só trabalhava com o rádio ligado em volume muito alto, além de ser "malcriada demais", a escritora conta que chegou a ligar para Dra. Neide para saber como lidar com a empregada, mas que a demissão restou inevitável:

Despedi-a com muito cuidado. Uma semana depois telefonou-me para desabafar: não conseguia emprego porque quando dizia às futuras patroas que fazia análise, elas tinham medo. Como era sozinha no Rio, não tivera onde ficar, e dormira duas noites no banco de uma praça, sofrendo frio. Senti-me culpada. Mas não havia jeito: não sou analista, e pouco podia ajudar num caso tão grave. Consoleime pensando que ela se tratava com a Dra. Neide, médica muito simpática, com quem falei uma vez por telefone para saber que atitude eu deveria tomar. (LISPECTOR, 1999a, p. 51).

Por meio desses relatos, percebemos o quão complexa é a relação empregada doméstica/patrão em nosso país, especificamente até a década de 1980, quando era muito comum que as empregadas domésticas dormissem nas casas de seus patrões, inclusive as construções da época contavam com a "dependência de empregada", que em uma estrutura micro, reproduz a casa grande e a senzala. O importante estudo "O serviço doméstico remunerado no Brasil: de criadas a trabalhadoras", de Hildete Pereira de Melo, que analisa o serviço doméstico remunerado no Brasil, apresenta as suas conclusões a partir de dados coletados pelo IBGE/PNAD, entre as décadas de 1970 a 1990 e nos oferece dados que corroboram o nosso pensamento:

\footnotetext{
Dirigentes do Sindicato dos Empregados Domésticos do Rio de Janeiro afirmam que só nos anos 80, a questão das domésticas com jornada de trabalho definida irrompe nos grandes centros urbanos. Tanto como uma reivindicação da classe como exigência da própria vida nesses centros (entrevista pessoal). Dois problemas envolvem essa questão. Primeiro, as domésticas externas/diaristas são mulheres pobres, com filhos menores, morando nas periferias das zonas metropolitanas, sem creches e escolas em tempo integral, mas que não têm outra forma de ganhar a vida. Segundo, a vida moderna nos grandes centros urbanos ocorre para que algumas patroas prefiram uma empregada que tenha moradia própria, porque a doméstica residente "rouba liberdade dentro de casa". Além disso, não oferecer alojamento e todas as refeições é uma maneira de cortar custos para a classe média. Dessa maneira, trabalhadores domésticos vivendo nas casas dos patrões tendem a desaparecer, portanto o oferecimento de casa e comida de antanho, ranço do escravismo, está sumindo paulatinamente nas metrópoles brasileiras. (MELO, 1998, p. 10-11).
} 
Entre as empregadas que teve, Clarice relata sobre essas quatro que em comum guardam alguma especificidade: uma que surpreendentemente se interessou pela leitura, a segunda que era vidente, a terceira que conquistou uma boa vida nos Estados Unidos e por fim, a que fazia análise, "juro”, diz Clarice. Com exceção da empregada que era vidente, as três outras empregadas causam surpresa na escritora porque se insurgem em aspectos que não são próprios de sua classe social: o hábito da leitura, conquistar uma boa vida fora do país e fazer análise. Aqui é a voz da mulher de classe média, de certa forma espantada com os aspectos narrados, ao ponto de considerar-lhes assunto para uma crônica.

Esse espanto é oriundo da relação intrínseca que se estabeleceu no Brasil entre patrões e empregadas domésticas, profissão proveniente do passado escravocrata do nosso país, razão pela qual a remuneração é, sob raras exceções, tão baixa quanto o seu reconhecimento. A relação de trabalho causava ainda mais estranhamento quando não havia uma diretriz legal que estabelecesse a questão de a empregada dormir na casa dos patrões, fato corriqueiro, pois como citamos, havia inclusive o espaço físico destinado para esse fim, geralmente planejado ao lado da cozinha e que só começa a mudar a partir das conquistas sociais da categoria, implementadas a partir da década de 1980, conforme aponta Melo, em seu estudo aqui já referido: “Contudo, as transformações no serviço doméstico remunerado objetivavam modificar a relação patroa/empregada doméstica, tornando-a menos pessoal, sem relações de parentesco fictícias e de ajuda à trabalhadora e sua família.” (MELO, 1998, p. 4).

É com essa sensação de estranhamento que analisamos trechos do conto "Um dia a menos". Nele a personagem Margarida Flores se encontra sozinha em casa, em um dia de domingo:

O dia começara às quatro da manhã, sempre acordara cedo, já encontrando na pequena copa a garrafa térmica cheia de café. Tomou uma xícara morna e lá ia deixá-la para Augusta lavar, quando se lembrou de que a velha Augusta pedira licença por um mês para ver seu filho. (LISPECTOR, 1999c, p. 85).

Margarida é órfã, mora sozinha e tem com Augusta uma relação em que os aspectos profissionais e pessoais restam profundamente entranhados, um exemplo do "parentesco fictício" referido por Melo em seu estudo, esta relação é caracterizadora da condição da empregada doméstica no Brasil, especificamente na década de 1970, quando foi escrito o conto "Um dia a menos", ou seja, a funcionária reside em sua casa, inclusive para sair tem de pedir licença, mas não integra a família. Embora percebamos que Augusta tem o seu espaço naquela casa, "E melhorou ainda mais quando sentou na poltrona recém-forrada de roxo (gosto de Augusta" (LISPECTOR, 1999c, p. 85), não podemos afirmar que há equidade nessa relação, basta lembrarmos que Margarida já ia deixar a xícara para Augusta lavar. 
O dia da personagem segue sem alterações, como é esperado em seu cotidiano, exceto por uma ligação telefônica recebida que, inclusive, havia sido feita por engano. Ela é uma personagem de trinta anos que vive dos rendimentos deixados pelos pais e que deixa a casa aos cuidados de Augusta: "Quanto a ela mesma, ela se guiava pelo fato de não ser casada, de ter a mesma empregada desde que nascera, de ser uma mulher de trinta anos de idade, pouco batom, roupa pálida...” (LISPECTOR, 1999c, p. 87).

Lembremo-nos de que no começo do conto o narrador usa a expressão "a velha $\mathrm{Au}$ gusta”, ora, se a empregada está na casa de Margarida desde que essa nascera, não podemos deixar de registrar que a doméstica, possivelmente, já tenha ultrapassado a idade de se aposentar, entretanto, os vínculos trabalhistas e pessoais se misturam de tal maneira que, ainda que tenha adquirido tal direito, permanece à disposição dessa família. Este é um retrato da empregada doméstica no Brasil e quando dizemos que os vínculos se misturam, observamos que o sacrifício exigido em troca é sempre maior para a doméstica.

Uma das irmãs de Clarice Lispector, Tania Kaufmman, publicou em 1975 A aventura de ser dona-de-casa (dona-de-casa vs. empregada), o livro é uma espécie de manual em que a autora aborda os problemas da relação entre patroa e empregada, apontando os caminhos para uma convivência harmônica, em que a patroa consiga "domar" a empregada, no trecho a seguir, podemos perceber de forma clara e representativa a questão a que nos referimos, sobre o quanto a linha que separa os vínculos pessoal e profissional é tênue, para Kaufmman, patroa e empregada são: “duas pessoas que o destino juntou na mesma casa, empenhadas num jogo nem sempre amistoso. E separadas por uma surda luta de classes que, não esqueçamos, é a base de toda a questão.” (KAUFMMAN, 1975, p. 23).

Este fato, porém, nem sempre é percebido, a empregada doméstica é o outro que não é enxergado, em um dado momento da narrativa, Margarida reflete: "Lembrou-se a troco de nada que havia milhões de pessoas com fome, na sua terra e nas outras terras. Iria sentir um mal-estar todas as vezes em que comesse” (LISPECTOR, 1999c, p. 88), entretanto, não há relato de como a personagem se sente em relação a sua empregada, tão naturalizada está essa convivência.

Durante a ligação telefônica a que nos referimos, Margarida falando sobre Augusta diz que ela é sua “empregada de criação" (LISPECTOR, 1999c, p. 91), uma expressão que não nos é estranha, ela sugere uma certa proximidade entre patrão e empregada, sendo que esta recebe a referência quando agrega às suas intermináveis funções a obrigação de criar os filhos da família para a qual presta serviço. O que guarda uma relação ainda mais direta com os períodos de escravidão, em que as escravas não podiam amamentar os seus próprios filhos, 
por exemplo, para amamentar os filhos da família que tinha a sua posse. O que nos lembra a análise de Alencastro da fotografia feita no Recife, por volta de 1860, por meio da qual ele conclui "Quase todo o Brasil cabe nessa foto"

Talvez por sugestão do fotógrafo, talvez porque tivesse ficado cansado na expectativa da foto, o menino inclinou-se e apoiou-se na ama. Segurou-a com as duas mãozinhas. Conhecia bem o cheiro dela, sua pele, seu calor. Fora do vulto da ama, ao lado do berço ou colado a ele nas horas diurnas e noturnas da amamentação, que seus olhos de bebê haviam se fixado e começado e enxergar o mundo. Por isso ele invadiu o espaço dela: ela era coisa sua, por amor e por direito de propriedade. (ALENCASTRO, 1997, p. 439-440).

A personagem Augusta ainda não havia completado a sua missão de cuidar da filha da família para quem trabalha e de quem recebe o título de "empregada de criação", uma realidade especificamente brasileira. A personagem supre, há anos, com a sua presença e com os seus serviços, a carência da patroa, que não tem projeções de uma vida diferente: "Para falar a verdade, não tinha fome. Só às vezes se animava com Augusta porque falavam, falavam e comiam, ah, comiam fora da dieta e nem engordavam! Mas Augusta ia se ausentar por um mês. Um mês é uma vida.” (LISPECTOR, 1999c, p. 92).

E então, vencida pelo tédio de sua própria vida, Margarida resolve tomar as pílulas que sua mãe falecida tomava para "dormir um bom soninho e acordar rosada" (LISPECTOR, 1999c, p. 93):

\footnotetext{
Não tinha nenhuma má intenção. Foi buscar a jarra e um copo. Abriu um dos vidros: tirou duas pequenas pílulas. Tinham gosto de mofo e açúcar. Não notava em si a menor má intenção. Mas ninguém no mundo saberá. E agora para sempre não se saberá julgar se foi por desequilíbrio ou enfim por um grande equilíbrio: copo após copo engoliu todas as pílulas dos três grandes vidros. (LISPECTOR, 1999c, p. 93).
}

A morte de Margarida nos lembra a morte de Macabéa, aliás, esse conto também é do ano de 1977: "Mas no segundo vidro pensou pela primeira vez na vida: 'Eu'. E não era um simples ensaio: era na verdade uma estreia." (LISPECTOR, 1999c, p. 93). Não se fala mais sobre Augusta no conto, a sua saída também nos lembra Macabéa é "discreta e pela porta dos fundos".

Não pretendemos com esta análise um julgamento moral da personagem Margarida, uma mulher de classe média, com suas complexidades, educada para a vida que teve, que até pensa no próximo, o que problematizamos é o quão naturalizada é a servidão das empregadas domésticas em relação a suas patroas, ao ponto de não mais se verem fora dessa espécie de devoção, como disse Clarice, em sua crônica "Por detrás da devoção".

Já na personagem Janair, do romance A paixão segundo G.H., encontramos um exemplo de superação de tal servidão, pois ela instiga G.H. a lhe dar visibilidade, por meio do desenho 
que deixa na parede da dependência de empregada que ocupava, desta forma, podemos concluir que não é G.H. que chega a Janair, mas esta que provoca a sua percepção. Sobre a personagem Janair, Roncador pontua: "Ao explorar literariamente os aspectos psicológicos do "ressentimento", da "humilhação" e da "alienação" da doméstica, Lispector parece querer reivindicar para essa categoria uma posição mais central na ficção brasileira." (RONCADOR, 2008, p. 143, grifos da autora).

A identidade da personagem G.H. é revelada com superficialidade, sabemos que ela estudou escultura e que busca um "destino maior", que não seja apenas o "enredo de uma vida”, nem seu nome é revelado, entretanto o leitor é convidado a adentrar em seu cotidiano de sensações.

G.H. apresenta o seu relato a partir de um acontecimento que inesperadamente lhe trouxe grandes reflexões: "Ontem de manhã - quando saí da sala para o quarto da empregada - nada me fazia supor que eu estava a um passo da descoberta de um império. A um passo de mim.” (LISPECTOR, 1998, p. 23). A personagem traçou para aquele dia um plano simples que consistia em realizar algumas atividades domésticas, que não lhes eram comuns: arrumaria o apartamento e deveria começar pelo quarto da empregada, para depois ir "subindo horizontalmente" e terminar por arrumar a si própria, porém, ao adentrar no ambiente, percebe com espanto que o quarto está inteiramente limpo: "Eram quase dez horas da manhã, e há muito tempo meu apartamento não me pertencia tanto. No dia anterior a empregada se despedira." (LISPECTOR, 1998, p. 24).

Percebemos pelo relato um pouco do que refletimos acerca das relações pessoal e profissional estarem tão misturadas, o fato de uma pessoa que não é de sua família residir em seu apartamento, faz com que G.H. não o sinta tão dela. Não podemos deixar de registrar que é Janair quem se demite, superando a servidão a que prestara, ainda que não tenhamos registro no romance do caminho tomado pela empregada. Não há, neste caso, uma figuração de Janair, ela é apenas rememorada por G.H.:

\footnotetext{
A lembrança da empregada ausente me coagia. Quis lembrar-me de seu rosto, e admirada não consegui - de tal modo ela acabara de me excluir de minha própria casa, como se me tivesse fechado a porta e me tivesse deixado remota em relação à minha moradia.” (LISPECTOR, 1998, p. 40).
}

Em uma das paredes da dependência de empregada, G.H. encontra um desenho rabiscado a carvão, era a representação de um homem, uma mulher e um cachorro, independentes entre si, a personagem interpreta o desenho como sendo o julgamento de Janair sobre a patroa: "[...] deixei finalmente vir a mim uma sensação que durante seis meses, por 
negligência e desinteresse, eu não me deixara ter: a do silencioso ódio daquela mulher." (LISPECTOR, 1998, p. 40).

O desenho consistia apenas num contorno sem definição, ao que G.H. interpreta: "O desenho não era um ornamento: era uma escrita" (LISPECTOR, 1998, p. 40), para ela, fica claro que aquelas formas abstratas representavam a maneira como Janair enxergava a vida da patroa: aparências e contornos, apenas: "Janair era a primeira pessoa realmente exterior de cujo olhar eu tomava consciência." (LISPECTOR, 1998, p. 40). A empregada é assim descrita:
Os traços - descobri sem prazer - eram traços de rainha. E também a postura: o corpo erecto, delgado, duro, liso, quase sem carne, ausência de seios e de ancas. E sua roupa? Não era de surpreender que eu a tivesse usado como se ela não tivesse presença: sob o pequeno avental, vestia-se sempre de marrom escuro ou de preto, o que a tornava toda escura e invisível - arrepiei-me ao descobrir que até agora eu não havia percebido que aquela mulher era uma invisível. (LISPEC- TOR, 1998, p. 41).

Invisível porque executa um trabalho sem visibilidade nem criatividade, que apenas aparece se não for feito, uma função que não lhe oferece possibilidades de crescimento intelectual, entretanto, é por meio dessa invisível e do desenho deixado por ela na parede, que G.H. ingressa em uma profunda experiência de reflexões e descobertas. Ao examinar o guarda-roupa vazio do quarto, encontra a barata que desencadeia todo o percurso da personagem em direção à definição da paixão e do seu contrário, neste estudo não tocaremos nesse ponto do livro, dada a complexa radicalidade da proposta de Clarice, vamos nos deter à relação entre Janair e sua patroa G.H., que conclui: "Perguntei-me se na verdade Janair teria me odiado - ou se fora eu, que sem sequer a ter olhado, a odiara.” (LISPECTOR, 1998, p. 43).

Assim, Janair só é enxergada pela patroa quando esta sai de sua vida institucionalizada e se desloca, inclusive fisicamente, para ver o outro, este escopo de enxergar o outro é uma tônica da literatura de Clarice que, a seu modo, não se furta à dor do próximo. Janair é a empregada doméstica que provoca a reflexão acerca de sua invisibilidade dentro da própria casa em que habitava, talvez por não suportar essa situação tenha se demitido, ou apenas tenha optado por outra forma de servidão, não sabemos, o fato é que os sentimentos provocados a partir de sua ausência acrescentam protagonismo a uma representação, em geral, tão secundária, fazendo de Janair o ponto de superação na servidão tão presente na profissão de empregada doméstica. Acrescentamos ainda que Janair é uma mulher negra: 
desenhadas, revi os traços finos e delicados que mal eram divisados no negror apagado da pele. (LISPECTOR, 1998, p. 41).

A cor da pele de Janair pode, de fato, ser um de seus modos de se calar, especialmente em um país como o Brasil que aponta para uma maioria negra entre os empregados domésticos, de acordo com dados da Organização Internacional do Trabalho:

No Brasil, o trabalho doméstico é realizado primordialmente por mulheres, em sua maioria negras. Menos de 30\% do total das trabalhadoras domésticas têm carteira de trabalho assinada e acesso à previdência social. A evolução da formalização do trabalho no Brasil, observada principalmente a partir de 2004, é ainda lenta para esta categoria e seus rendimentos seguem sendo mais baixos do que aqueles auferidos pelas demais categorias profissionais. (OIT, 2010, p. 12).

Esse dado diz muito sobre as reminiscências de um passado escravocrata que se repete por meio de um trabalho associado a pouca necessidade de especialização, usada para justificar os baixos salários e a falta de reconhecimento.

Procuramos, neste estudo, refletir sobre as relações estabelecidas entre patrão e empregada doméstica, concluímos que parte dos reflexos dessa relação pode ser compreendida por meio da figuração dessas profissionais na obra de Clarice Lispector, em que percebemos a naturalização de uma exploração que deveria causar estranhamento, a escritora, que tem uma forma bastante original de tocar nas questões sociais, expõe essa realidade a partir de um lugar de classe, a classe média que era a sua e que figura entre tantas de suas personagens.

Essa mulher de classe média reproduz em um micro espaço a dinâmica das casas grandes e das senzalas que mantinham escravos à disposição dos afazeres domésticos, e não apenas, como a história nos diz Hoje, mesmo com a conquista de direitos quando, finalmente, as relações trabalhistas das domésticas foram estabelecidas e equiparadas às relações dos demais trabalhadores pela Lei-Complementar 150/2015, essa categoria profissional permanece em uma condição de vulnerabilidade, essa Lei, por exemplo, equipara os direitos entre trabalhadores, mas apenas em 2020, por meio do Decreto 10.410, os trabalhadores domésticos puderam contar para a sua aposentadoria o tempo de trabalho exercido, mesmo que não tenha havido o respectivo recolhimento previdenciário, independentemente de ser ou não doméstico quando atingir a idade de se aposentar. Como não pensar em Augusta, personagem "Um dia a menos", que se manteve à disposição daquela família até a sua velhice? E por outro lado, como não pensar em Janair, que impôs sua visibilidade a uma patroa alheia a sua presença.

Aliás, não podemos deixar de citar que, situada entre Augusta e Janair, está a personagem Eremita, do conto "A criada", a jovem empregada doméstica de 19 anos que é descrita de forma bastante poética, com uma atmosfera de mistério: 
Porque tinha suas ausências. O rosto se perdia numa tristeza impessoal e sem rugas. Uma tristeza mais antiga que o seu espírito. Os olhos paravam vazios; diria mesmo um pouco ásperos. A pessoa que estivesse a seu lado sofria e nada podia fazer. Só esperar. (LISPECTOR, 2020, p. 111).

Eremita, "a misteriosa infante", transita em um território imaginado pelo narrador e que justificaria a dificuldade de defini-la como pessoa, a personagem está em um nível de profundidade inatingível, porém de lá submerge para a função a qual exerce: “Assim, quando emergia, era uma criada. A quem chamavam constantemente da escuridão de seu atalho para funções menores, para lavar roupa, enxugar o chão, servir a uns e outros.” (LISPECTOR, 2020, p. 112).

Em Eremita encontramos os mistérios de Janair, que deixou tantas perguntas a G.H. e a existência para serviços menores de Augusta, com a sua vida inteira dedicada a uma família que nunca fora sua. Desta forma, a obra de arte genuína opera politicamente, fazendo saltar de suas páginas, no caso da literatura, uma realidade que está tão naturalizada entre nós, que, às vezes, nos escapa o seu reconhecimento e o seu questionamento. É pensando a partir do que Clarice nos propõe ao apresentar essas mulheres - patroas e empregadas - que percebemos a fissura existente e os desafios em termos da implantação de políticas públicas que revertam a desvalorização e o desprestígio dessa categoria profissional diante da sociedade brasileira.

\title{
SERVICE AND OVERCOMING: \\ A STUDY ABOUT THE PRESENCE OF THE HOUSEMAID IN THE LITERATURE OF CLARICE LISPECTOR
}

\begin{abstract}
This study has as its object the figuration of the housemaid in the literature of Clarice Lispector, it intends to reflect the relations originating from a Brazilian slave past that leads to the way in which housemaid are hired until today. The housemaid is present in Clarice's short stories and novels, as well, as in chronicles that she published in Jornal do Brasil. We paused for a closer analysis about Augusta, of the short story "A day less" and Janair, of the novel The passion according to G.H. We know that domestic work also encompasses the male gender, however, in this approach, we establish as a cutout domestic work developed only by women for two reasons: the first is linked to the very figuration in Clarice's work, in which the characters are female, the second refers to the fact that the domestic work is done mainly by women. In this way, we hope, by approaching the work of a writer who was so often charged for not having a socially engaged writing, to contribute to the debate about the relationships that precarize and devalue domestic work in Brazil.
\end{abstract}

KEYWORDS: Clarice Lispector; housemaid; invisibility.

\section{REFERÊNCIAS}

ALENCASTRO, Luiz Felipe de. História da vida privada no Brasil: Império - a corte e a modernidade nacional. São Paulo: Companhia da Letras, 1997. v. 2.

FRANCIS, Paulo. Clarice: impressões de uma mulher que lutou sozinha. Folha de São Paulo, São Paulo, p. 43, 15/12/1977. 
GOTLIB, Nádia Batella. Quando o objeto, cultural, é a mulher. A hora da estrela: edição com manuscritos e ensaios inéditos/Clarice Lispector. Rio de Janeiro: Rocco, 2017, p. 181-193.

KAUFMMAN, Tania. A aventura de ser dona-de-casa (dona-de-casa vs. empregada): um assunto sério visto com bom humor. Rio de Janeiro: Artenova, 1975.

LISPECTOR, Clarice. A paixão segundo G.H. Rio de Janeiro: Rocco, 1998.

. Para não esquecer. Rio de Janeiro: Rocco, 1999.

- A descoberta do mundo. Rio de Janeiro: Rocco, 1999a.

. Laços de família. Rio de Janeiro: Rocco, 1999b.

. A bela e a fera. Rio de Janeiro: Rocco, 1999c.

- A hora da estrela. Rio de Janeiro: Rocco, 2007.

Felicidade clandestina. Rio de Janeiro: Rocco, 2020.

MELO, Hildete Pereira de Melo. O serviço doméstico remunerado no Brasil: de criadas a trabalhadoras. Rio de Janeiro: Ipea, 1998.

Organização Internacional do Trabalho. Trabalho doméstico no Brasil: rumo ao reconhecimento institucional. Brasília: ILO, 2010.

RONCADOR, Sônia. A doméstica imaginária: literatura, testemunhos e a invenção da empregada doméstica no Brasil (1889-1999). Brasília: Editora da Universidade de Brasília, 2008.

\section{ENTREVISTA GRAVADA}

Suzana Amaral, entrevista concedida à TV Cultura em 1999. Programa Trinta anos incríveis: https://www.youtube.com/watch?v=aIflu42J_U0, acessado em 17/11/2020.

Agradecimentos: Agradeço e dedico este estudo a todas as mulheres que fazem parte da minha vida: Avós, Mãe, Filha, Tias, Primas e Amigas.

Recebido em: 30/09/2020.

Aprovado em: 24/11/2020. 